\title{
Restoran Seçiminde Kişiliğin Rolü: Sakarya Örneği
}

\author{
The Role of Personality in Restaurant Choice: Case of Sakarya
}

\author{
Ŏguz TÜRKAY* \\ Burak ATASOY**
}

$\ddot{O} Z$

Insan yaşamında görülen refah ve boş zaman artışı, bireylerin dışarıda daha fazla vakit geçirmesine dolayısıyla daha fazla etkinliğe katılmasına olanak sağlamıştır. Bu etkinlikler içerisinde en sık tercih edilenlerden birisi ise insanların dışarıda yemek yemesidir. Restoranlarda yemek deneyimi yaşayan insanların restoran tercihleri kişilik özelliklerine göre farklılaşabilmektedir. Restoran tercihleri kapsaminda; restoran özelliklerine atfedilen önem ile belli bir bölgedeki restoranlara atfedilen nitelik öne çıkmaktadır. Bu kapsamda çalışmanın amacı, kişilik ile restoran özelliklerine atfedilen önem ve Sakarya restoranlarının algılan niteliği arasındaki karşılıklı ilişkileri incelemektir. Araştırma bulguları yenilikçi, sempatik ve dişa dönük kişilikler için personel tutum ve davranışlarl, restoranın konforu ve yemeğin özelliklerinin öne çıkan özellikler olduğunu göstermektedir. Gelenekçi ve sessiz kişilikler için ise restoranın fiziksel özellikleri önemli görülmektedir. Ayrıca, Sakarya restoranlarını nitelikli görme konusu en fazla oranda yenilikçi kişilik özelliği ile ilişkilidir. Dolaylsıyla, sonuçlar tüketicilerin kişilik özelliklerine göre restoran özelliklerine önem ve nitelik atfettiğini doğrulamaktadır.

ANAHTAR KELIMELER

Kişilik, Restoran Seçimi, Tüketici, Restoran Özellikleri

\begin{abstract}
The increase in well-being and leisure time in human life has enabled individuals to spend more time outside and thus participate in more activities. One of the most preferred of these activities is people's dining out. Restaurant preferences of people who have a dining experience in restaurants may differ according to their personality traits. Within the scope of restaurant preferences; The importance attributed to restaurant features and the quality attributed to restaurants in a particular region stand out. In this context, the aim of the study is to examine the mutual relationships between personality and the importance attributed to restaurant features and the perceived quality of Sakarya restaurants. Research findings show that staff attitudes and behaviors, comfort of the restaurant and features of the food are prominent features for innovative, sympathetic and extroverted personalities. For traditional and quiet personalities, the physical features of the restaurant are considered important. In addition, the subject of seeing Sakarya restaurants qualified is most associated with the innovative personality trait. Therefore, the results confirm that consumers attribute importance and quality to restaurant features based on their personality traits.
\end{abstract}

\section{KEYWORDS}

Personality, Restaurant Choice, Consumer, Restaurant Features

\begin{tabular}{|c|c|c|}
\hline \multicolumn{2}{|r|}{$\begin{array}{c}\text { Makale Geliş Tarihi / Submission Date } \\
10.02 .2020\end{array}$} & $\begin{array}{c}\text { Makale Kabul Tarihi / Date of Acceptance } \\
13.05 .2020\end{array}$ \\
\hline Atıf & $\begin{array}{l}\text { Türkay, O. ve Atasoy, B. (2020). Re } \\
\text { Bilimler Meslek Yüksekokulu Dergisi, }\end{array}$ & in Rolü: Sakarya Örneği. Selçuk Üniversitesi Sosyal \\
\hline
\end{tabular}

\footnotetext{
* Prof. Dr., Sakarya Uygulamalı Bilimler Üniversitesi Turizm Fakültesi Gastronomi ve Mutfak Sanatları Anabilim Dalı, turkay@ subu.edu.tr, ORCID: 0000-0002-0752-6799

** Arş. Gör., Sakarya Uygulamalı Bilimler Üniversitesi Turizm Fakültesi Turizm Rehberliği Anabilim Dalı, burakatasoy@ subu.edu.tr, ORCID: 0000-0002-9742-8112
} 


\section{GİRIŞ}

İnsanoğlunun gelirinde meydana gelen artış, yaşam ve tüketim biçimlerini önemli düzeyde etkilemektedir. En önemli değişikliklerden birisi olarak "dışarıda yemek yeme" eğilimi artmaktadır. Başka bir deyişle restoranlarda yemek yeme konusu önemli bir tercih olmakta ve bir alışkanlığa dönüşmektedir (Yüksekbilgili, 2014). Rutin hayatın sıradanlığından kurtulmak, farklı deneyim yaşamak, birlikte zaman geçirmek ve eşsiz tatları denemek amacıyla insanlar restoranlara yönelmektedir. Kadınların da çalışma hayatına aktif katılımı, zaman tasarrufu isteği, sosyalleşme, eğlenceli vakit geçirme ve yenilik arayışı gibi etmenler insanların restoranlara yönelmesi ardındaki diğer faktörler olarak ele alınmaktadır (Albayrak, 2014). Bu anlamda, dışarıda yemek yemenin artan bir eğilimi yansıttığı ve restoran işletmeciliğinin gittikçe daha popüler olan bir alan olduğu görülmektedir.

Türkiye' de hazır yemek sektörünün yıllık 24 milyar dolarlık işlem hacmi oluşturduğu tahmin edilmekte ve bu rakamın da \%35'inin restoranlarca üretildiği öngörülmektedir (TAVAK, 2018). Restoranlar farklı ihtiyaçlara cevap üretecek şekilde tasarlanmakta ve çeşitlenmektedir. Bu durumda restoranlara yönelik talebin de arttığı ve bahsedilen harcama düzeylerinde artış beklendiği ifade edilmelidir. Ama aynı zamanda küçük işletme sayısının fazla olmasına da bağlı olarak restoran işletmeleri rekabetin yoğun olduğu, personel giderleri gibi yüksek maliyet unsurları ile mücadele edildiği ve buna bağlı olarak da kar marjının gittikçe düşme eğiliminde olduğu anlaşılmaktadır (Assaf, Deery and Jago, 2010). Bu durumda restoranlar için başarı unsurlarını analiz etmek, yiyecek-içecek endüstri için yararlı bilgiler ortaya koyabilir. Müşterilerin kişilik özellikleri gibi önemli belirleyicilerin restoran tercihine etkisini incelemek önemli sonuçlar doğurabilecek bir yaklaşım olarak görülmektedir. Restoran seçimi kararı her ne kadar yemek çeşitliliği, fiyat, atmosfer gibi unsurlardan etkilense de insanların kişilik özellikleri de bu süreçte rol oynayan bir etmendir. Benzer şekilde dışarıda yemek yeme olgusu bir deneyim olarak kabul edilmekte ve bu deneyimin algılanması üzerinde bireyin karekteristik özelliklerinin rol oynadığı ifade edilmektedir (Cömert \& Özata, 2016).

İnsanların davranışını analiz etmek ve hangi etmenlerden dolayı yiyecek-içecek işletmelerine veya restoranlara yöneldiğini anlamak şüphesiz önem arz etmektedir (Güllü \& Atasoy, 2019). Ancak insan unsurunun doğası gereği bu durum karmaşık ve birden çok etmenin rol oynadığı bir süreci belirtmektedir. Tüketicilerin restoranlara yönelirken dikkate aldı ̆̆ı faktörlerin analizinde bazı noksanlıkların olduğu insanların restoran tercihinde dikkate aldığı kriterlerin farklılaştığı ifade edilmektedir (Arıker, 2012). Restoran işletmelerinin rekabette başarısının tek yolu tüketici memnuniyetini her yönüyle sağlamak olarak vurgulanmaktadır (Ekincek \& Önçel, 2017).

Restoran yöneticilerinin müşteri memnuniyeti sağlamak amacıyla hizmet kalitesini geliştirmesi, gıda kalitesine ve fiziksel çevre unsurlarına önem vermesi gerekmektedir (Van der Waldt ve diğ., 2014). Bu nedenle de insanların hangi faktörlere bağlı olarak restoran tercihinde bulunduklarını bilmeleri önem arz etmektedir. Böylelikle hedef müşterileriyle daha etkin ve hızlı pazarlama iletişimi kurmalarının olası olacağı, müşterinin yaklaşımına uygun bir kalite standardı oluşturabilecekleri ifade edilebilir. Restoran işletmelerinin faaliyette bulundukları pazar içerisinde rekabet avantajı elde etmek istemesi müşterilerinin hangi gerekçeler veya hangi istek ve beklentiler doğrultusunda ürün veya hizmetlerden faydalandığını bilmelerini gerektirmektedir.

Bilinen yaygın restoran tercih kriterleri içerisinde fiyat, atmosfer, menü çeşitliliği, yiyeceklerin kalitesi, servis kalitesi, restoranın marka değeri, misafirperverlik, gizlilik gibi unsurların etkili olduğu kabul edilmektedir (Albayrak, 2014; Islam diğ., 2018). Ancak tüketim biçimleri veya alışkanlıkları cinsiyete, inanışa, eğitim düzeyine, yaşam biçimi gibi kişisel özelliklere göre de farklılaşabilmektedir (Canoğlıu \& Ball1, 2018). Her ne kadar farklı etmenler söz konusu olsa da insanların kişilik özelliklerinin de restoran seçim sürecinde büyük bir öneme sahip olduğu düşünülebilir. Bu araştırmanın amacı tüketicilerin restoran tercihinde önemli görülen seçimlerle kişilik özelliklerinin ilişkisini tespit etmektir. Bu kapsamda araştırma; restoran tercihinde kişilik unsurunun rolünü, kişilik - restoran özelliklerine atfedilen önem -Sakarya restoranların algllanan niteliği değişkenleri arasındaki ilişkiyi ortaya koyarak analiz etmeye odaklanmaktadır.

\section{LITERATÜR TARAMASI}

\subsection{Restoran Özelliklerinin Müşteriler Tarafından Algılanması}

Sanayileşme ve kentleşme dışarıda yeme deneyiminin artmasında önemli bir role sahiptir. Artan boş zaman ve gelir insanların daha fazla etkinliğe katılmasına firsat sağlamış ve restoranlar bu etkinlikler içerisinde sıkça tercih edilen hizmet işletmeleri olmuştur (Yüncü \& Sevim, 2019). Eski dönemlerde seyahat eden insanların yeme-içme ihtiyaçlarını gidermek amacıyla faaliyette bulunan restoran işletmeleri bugün geldiği nokta itibariyle farklı bir konuma sahiptir. Restoranlar artık sadece yeme-içme hizmeti vermenin yanı sıra 
tüketicilerin sosyal, psikolojik ve kültürel beklentilerini karşılayan işletmeler olarak kabul edilmektedir (Ertürk, 2018).

Panthi \& Karki (2018), insanların restoran özellikleri içerisinde algılamalarını etkileyen faktörlerin çok değişken olduğundan ve bu unsurların restoranları tekrar ziyaret niyetini etkilediğinden söz etmektedir. Ayrıca yazarlar bu unsurlardan en önemlilerden birinin fiyat olduğunu belirtmekte ve hatta fiyatı satın alma davranışında en etkili etmen olarak değerlendirmektedir. Türkay ise (2018), restoran işletmesinin tüketiciye sunduğu deneyime göre fiyat algısının da değiştiğinden söz etmekte ve fiyat unsurunu piyasanın yapı taşı olarak ele almaktadır. Öte yandan Filion \& Powell (2009), tüketicilerin restoranlara ilişkin algıları üzerinde hem deneyim öncesi hem de deneyim sonrası önem verdiği bir unsurun da gida güvenliği olduğundan söz etmektedir. Bu etmenler dikkate alınarak restoranların müşteri sadakati sağlaması önem arz etmektedir. Zira yeni müşteriler elde etmek ekonomi açısından mevcut müşterileri korumaya göre daha maliyetli olarak değerlendirilmektedir (Untaru \& Neacșu, 2012).

Dinçer \& Güzel (2018), restoran işletmelerinde çalınan arka plan müziği gibi diğer fiziksel çevre unsurlarının tüketicilerin kendilerini daha iyi ve rahat hissetmelerinde rol oynadığını, dolayısıyla restoran seçiminde önemli olduğunu belirtmektedir. Bu kapsamda tüketicilerin olumlu veya olumsuz restoran deneyimlerinde çevreye ilişkin değerlerin söz konusu olduğu ve bu noktada bu etmenin farkında olan işletmelerin öne çıkacağı yorumunda bulunulabilir. Jung ve diğ., (2015) ise, restoran seçimine ilişkin karar verme sürecinde genellikle gıda kalitesi, fiyat, hizmet kalitesi ve restoranın atmosferi gibi konuların önemine dikkat çekmektedir. Öte yandan hizmet kalitesi ve performansa ilişkin tüketici algısının da öneminden bahsedilmekte, restoran seçimi ve tekrar satın alma üzerinde büyük bir etkiye sahip olduğu ifade edilmektedir (Kim \& Chung, 2011). Bu kapsamda özellikle atmosfer, fiyat, lezzet, hizmet kalitesi, restoranın dekor ve diğer fiziksel çevre unsurları, hijyen ve sanitasyon gibi etmenlerin müşterilerin restoranlara ilişkin deneyimlerini etkilediği söylenebilir.

\subsection{Restoran Seçiminde Etkili Olan Faktörler}

Restoranlarda sunulan yiyecek ve içecekler, tüketicinin beslenme ihtiyacının yanı sıra psikolojik ve sosyolojik beklentilerini de karşılamaktadır (Çalışkan, 2013). İnsanlar, restoranlara yönelerek farklı deneyim yaşama, yöresel, eşsiz gıda tüketme ve birlikte zaman geçirme gibi sosyolojik ve fizyolojik ihtiyaçlarını gidermektedir. Ancak insanların dışarıda yeme motivasyonları gibi hangi gerekçeler neticesinde restoran tercihinde bulunduklarını anlamak önem arz eden bir diğer husustur.

Ertürk (2018), arkadaşlarla vakit geçirme, farklı ortamda bulunma, özel günleri kutlama, sosyalleşmek, eğlenmek, farklı lezzetleri deneyimleme, çocukların isteği ve yemek yapmaya yeterince zaman bulamama gibi sosyal ve psikolojik etmenler neticesinde insanların restoranlarda yemek deneyimi yaşadıklarından söz etmektedir. Nişancı ve diğ., (2018), insanlarında dışarıda yeme isteklerinin psikolojik, durumsal, itibar ve sosyalleşme gibi faktörlerden kaynaklandığından söz etmektedir. Ayrıca yazarlar çalışmalarında tüketicilerin restoranlarda yeme nedenleri arasında en etkili unsurun ise aile ve arkadaşlarla zaman geçirme olduğunu belirtmektedir. Benzer şekilde Bekar \& Dönmez (2016), tüketicilerin dışarıda yemek yeme nedenlerini araştırdığ 1 çalışmasında psikolojik, sosyolojik, zorunluluk ve ekonomik gibi faktörlerin etkili olduğunu ifade etmektedir. Dışarıda yemek deneyiminin fizyolojik olduğu gibi statü, prestij ve ruh halinde değişim gibi psikolojik ve sosyolojik nedenlerinin olduğunu söylemek önem arz etmektedir (Çetin \& Yayli, 2019).

Albayrak (2015), restoranların özellikleri, atmosferi, temizliği, konumu, fazla kalabalık olmaması, yiyecek ve içecek kalitesi, hizmet kalitesi ve parasal değer gibi unsurların insanların restoran seçiminde etkili olduğunu belirtmektedir. Yöresel yiyecek ve içecekler de tüketicinin restoran seçiminde rol oynamaktadır. Özellikle yerel gıdaların daha sağlıklı ve kaliteli olduğunu düşünen insanlar, bir yöreye özgü yiyecek ve içecek sunan restoranlara yönelebilmektedir (Çulha \& Dağkıran, 2016). Bu durumun arka planında sağlıklı beslenme ve otantik deneyim yaşama gibi motivasyonların rol oynadığı ve bu etkenler neticesinde insanların restoran seçiminde bulundukları söylenebilir. Öte yandan otopark, servis düzeni, reklam hizmetleri ve müzik gibi imkânlar da tüketicilerin restoran seçiminde önem arz eden faktörler arasında yer almaktadır (Yüksekbilgili, 2014).

Nişancı di ̌̆., (2018), tüketicilerin restoran seçiminde etkili olan unsurları restoranın temizliği, yemeklerin kalitesi ve çalışanların davranışı şeklinde ifade etmektedir. Canoğlu \& Ballı (2018), insanların kebap restoranları seçiminde etkili olan faktörleri incelediği çalışmasında ise yiyecek ve içeceklerin lezzeti, tazeliği ve temizliğine dikkat çekmektedir. Bu unsurların yanında restoran seçiminde atmosferinde önemli bir yere sahip olduğu söylenebilir. Artık tüketiciler restoran seçerken statünün bir parçası olarak düşünmekte ve bu doğrultuda restoran seçiminde bulunmaktadır (Çetin \& Yayli, 2019). Ancak genel olarak restoran seçiminde 
tüketiciler açısından etkili olan unsurlar yemek kalitesi, çeşitliliği, fiyat, atmosfer ve konum şeklinde ifade edilebilir (Özdemir, 2010).

Bütün bu psikolojik ve sosyolojik etkenlerin çeşitliliği, bu tür belirleyici olguların kökeninde yatan temel unsuru ele almaya gerektirmektedir. Bu nedenle kişilik, insan davranışını şekillendiren temel bir belirleyici olarak ele alınmaktadır.

\subsection{Kişilik Özelliklerinin Restoran Seçiminde Rolü}

Restoran seçiminde yukarıda dikkat çekilen unsurların hemen hepsini belli oranda açıklayacağ düşünülen kişilik faktörünün rol oynaması muhtemeldir. Metz (2014), kişilik özelliklerinin restoran seçiminde etkili olduğundan söz etmektedir. Yazar insanların gida tüketim biçimlerinin kişilik özelliklerine bağlı olarak farklılaştığını vurgulamaktadır. Bu noktada insanların hızlı servis sunan restoranları tercih etmesi (fast-food) veya kimilerinin temalı restoranlara yönelmesi örnek olarak değerlendirilebilir (Mason ve diğ., 2013). Ha (2018), kişilik kavramını insanın kendine özgü olan çevreye ya da topluma yönelik tutum ve davranışlarının bütünü şeklinde ifade edilmektedir. Ayrıca çalışmada insanların restoran tercihleri ile kişilik yapıları arasında güçlü bir ilişki olduğundan söz etmektedir. Dolayısıyla tüketicinin özelliklerinden biri olarak kişiliğin restoran seçiminde etkisinin insanın karakteristik özellikleriyle ilgili olduğu söylenebilir.

Sayg11 ve diğ., (2017), bireyleri diğer insanlardan ayıran ve bireyin kendine özgü özellikler bütününden kişilik olarak bahsetmektedir. Başka bir anlatımda ise kişilik, insanın kendine has, tutarlı, öngörülebilir unsurları içeren ve insan ile dış çevre arasındaki ilişkiyi ortaya çıkaran özellikler şeklinde tanımlanmaktadır (Ulusoy ve diğ., 2018). McCrae \& Costa (2008), "nevrotiklik, dışadönüklük, deneyime açıklık, uyumluluk, dürüstlük" şeklinde beş temel kişilik boyutundan söz etmektedir. Yazarlar, nevrotik kişilerin "mükemmeliyetçi ve karamsar", dişadönük kişilerin "sosyal, arkadaşlık bağı güçlü ve iyimser", deneyime açık kişilerin "hobileri olan, farklı, ilgili, yaratıcı", uyumlu kişilerin "inançlı, atfedici, işbirlikçi, itibarcı" ve dürüst kişilerin ise "lider, uyumlu, uzman" olduğunu ifade etmektedir.

Hjalager (2003), kişilik özelliklerine göre tüketicilerden bahsederken rekreasyonel tüketicilerin yabanc1 yiyecekleri sunan restoranları çok tercih etmediklerini ve daha çok birlikte ve tanınmış yerlerde yemek deneyiminde bulunduğundan söz etmektedir. Öte yandan, varoluşçu tüketicilerin dişarıda yemek yeme deneyimi sadece temel yeme-içme eyleminde bulunmanın ötesindedir. Zira bu kitlenin restoranlara yönelmesinin ardında yerel veya bölgesel düzeyde yiyecek ve içeceklere ilişkin detaylı bir bilgi edinim ve kişisel gelişim söz konusudur. Bu turist tipolojilerinin kalabalık zincir restoranlar yerine sadece yerel halkın bulunduğu özel yiyecek-içecek işletmelerine yöneldiği ifade edilmektedir.

Kivela \& Crotts (2006), şaşırtıcı turistten bahsetmekte ve bu kitlenin bilindik çokça tercih edilen restoranlara yöneldiğinden söz etmektedir. Ayrıca bu grubun yiyecek ve içeceklerin kalitesinden çok, miktarının ön planda olduğu zincir restoranları tercih ettiği belirtilmektedir. Egzotik yiyecek-içecek sunan restoranların bu tipolojiye uzak olduğu ifade edilmektedir. Öte yandan deneyimci turist tipolojilerinin ise modaya uygun, yenilikçi, şık ve lüks arayan bir kişiliğe sahip oldukları ve buna uyan restoranlara yöneldikleri ifade edilmektedir.

Yüksekbilgili (2014), tüketicilerin restoran seçiminde kişilik özelliklerine dikkat çekmekte ve farklı karakteristik özelliklere sahip bireylerin farklı restoranlara yöneldiğinden söz etmektedir. Yazar, insanların cinsiyeti, eğitim düzeyi ve yaşı gibi unsurların etkili olduğunu ifade etmektedir. Arıker (2012), restoran seçimi ve tüketicilerin demografik özellikleri arasında bir ilişki olup olmadığını araştırmıştır. Gelir, eğitim, medeni durum, yaş, çocuk durumu ve meslek gibi kişilik özellikleri ile yiyecek-içecek tüketimi, fiyat, kredi kartıyla ödeme, çocuklarla ilgili kriterler, kıyafet tercihi, mutfak türü, şarap listesi, canlı müzik gibi restoran seçim kriterli arasında ilişki olduğu sonucuna ulaşmıştır.

Albayrak (2014), restoran işletmelerinin müşteri memnuniyetini arttırması dolayısıyla rekabet avantajı elde etmesinde, müşterinin restoran niteliklerini değerlendirme sürecine odaklanılmasından söz etmektedir. Yazar, restoran işletmelerinin uygun havalandırma ve klima sistemleri kullanarak istenmeyen kokuları yok etmesini ve şeffaf ışıklandırma sistemleri kullanarak müşteriyi rahatsız etmeyecek bir aydınlatmanın benimsenmesi gibi konuların müşteri tarafından değerlendirilen niteliklerden bazıları olarak ifade etmektedir. Almohaimmeed (2017) ise, restoran tarafından müşteriye verilen güvencenin kişilik özellikleriyle ilişkisinden ve deneyim sonrası değerlendirmede rol oynayan bir diğer nitelik olduğundan söz etmekledir. Akşit (2019), çocuklu ailelerin restoran seçim kriterlerini incelediği çalışmada yaş, eğitim, meslek, gelir gibi kişisel faktörlerin rol oynadığını ifade etmekte ve aynı zamanda bu etmenlerin restoran niteliklerini değerlendirme sürecinde de etkili olduğunu belirtmektedir. 


\section{YÖNTEM}

$\mathrm{Bu}$ çalışmanın amacı, restoran tercihinde tüketicilerin kişilik özelliklerinin rolünü belirlemek ve restoran özelliklerine atfedilen önem düzeylerini kişilik açısından değerlendirmek olarak ifade edilebilir. Bunun yanında, kişilik ve restoran tercih kriterleri açısından Sakarya restoranlarına yönelik değerlendirmenin ne şekilde değiştiğini de öğrenmek amaçlanmıştır. Bu araştırma deneme modeli esasına dayanmakta ve amacı bakımından açıklayıcı araştırma özelliği taşımaktadır. Bu kapsamda araştırmanın çalışma evreni Sakarya ili Serdivan ilçesinde yer alan günlük restoranlar ve giderek yaygınlaşan kafe konseptindeki restoranlar olarak ifade edilebilir. Birden farklı restoran konseptine sahip olması ve genç nüfusun yoğun olmasından dolayı çalışma evreni olarak Serdivan ilçesi tercih edilmiştir. Araştırma örneklemi ise 448 katılımcı olarak belirlenmiştir.

Çalışma kapsamında restoran tercih kriterleri Yüksel \& Yüksel (2003) ve kişilik faktörleri ise Atak (2013)'den derlenerek araştırma ölçeği elde edilmiştir. Kişilik ölçeği "big five" olarak adlandırılan beş boyutlu kişilik ölçeğinin her bir boyutunun birbirinin zıddı olan ikişer ifade ile ölçümüne dayanan ve daha önce kullanılarak geçerli sonuç elde edilen halidir. Dolayısıyla, beş kişilik özelliği zıddı olan özelliklerle birlikte ölçülmek suretiyle on boyut elde edilmiştir. Atak (2013) her bir kişilik özelliğinin zıddı ile aynı yönde oylandığını tespit ederek bu iki ifadenin tek boyutu ölçtüğünü kanıtlamış olmasına rağmen bu çalışmada her bir kişilik özelliği zıddı ile birlikte ayrı iki boyut olarak ele alınmıştır. Örneğin, yenilikçilik boyutun yanında gelenekçilik boyutu da ayrı bir boyut olarak ilişki analizlerine sokulmuştur. Araştırma ölçeğinde yer alan ifadeler 5'li derecelendirme (1=Hiç önemli değil, 2=Önemli değil, 3=Ne önemli Ne değil, 4=Önemli, 5=Kesinlikle Önemli) şeklinde ölçeklendirilmiştir. Sakarya restoranlarının genel değerlendirmesi kapsamında da yedi adet ifade geliştirilmiştir. Bu ifadeler; Sakarya restoranlarının talebe duyarlı olması, yeterli fiziksel donanıma sahip olması, kaliteli olması, personelinin yeterli nitelikte olması, çalışanlarının hizmete istekli olması, gıda güvenliği ve hijyene dikkat edilmesi ve bu restoranlara her konuda güven duyulması konularına katılım düzeyini ölçen 5'li Likert tipi derecelendirme ile ölçeklendirilmiştir.

\section{ARAŞTIRMA BULGULARI}

Araştırmaya katılanlar büyük bir oranla erkek $(\% 62,1)$ ve $18-25$ yaş aralındadır. Gelir bakımından büyük çoğunluğun $(\% 37,7)$ 1001-2000 arasında gelire sahip olduğu ifade edilebilir.

Tablo 1. Katılımcıların Demografik Özellikleri

\begin{tabular}{|lcc|}
\hline Cinsiyet & Sıklık & Yüzde \\
\hline Erkek & 278 & 62,1 \\
Kadın & 168 & 37,5 \\
Cevapsız & 2 & 0,4 \\
\hline Yaş & Sıklık & Yüzde \\
\hline $18-25$ & 204 & 45,5 \\
$26-35$ & 142 & 31,7 \\
$36-45$ & 58 & 12,9 \\
$46-55$ & 24 & 5,4 \\
56-65 & 15 & 3,3 \\
66 ve üstü & 5 & 1,1 \\
\hline Aylık Gelir & Sıklık & Yüzde \\
\hline 1000 TL ve altı & 114 & 25,4 \\
1001-2000 TL & 169 & 37,7 \\
2001-3000 TL & 80 & 17,9 \\
3001-5000 TL & 60 & 13,4 \\
5001 TL ve üstü & 21 & 4,7 \\
Cevapsız & 4 & 0,9 \\
\hline
\end{tabular}




\subsection{Faktör Analizi}

Araştırma kapsamında, restoran tercih kriterleri ölçeğinde bulunan ifadeleri test edebilmek adına keşifsel faktör analizi gerçekleştirilmiştir. Faktör analizi, ifadeleri azaltan ve bu ifadelerin boyutlarını belirleyen bir teknik olarak tanımlanmaktadır (Jollifie, 2002). Faktör analizi kapsamında Varimax tekniği tercih edilmiş ve faktör yükü 0,40 altında olan değişkenler değerlendirmeye tabi tutulmamıştır. Analiz sonucuna göre KMO değerinin $(0,88)$ olması ve yanı sıra Bartlett Küresellik testi sonucunun anlamlı $(p<0,05)$ olması verinin faktör analizine uygunluğuna işaret etmektedir.

Keşifsel faktör analizi kapsamında boyutların açıkladığı varyans oranına göre büyükten küçüğe sıralanması "personelin tutum ve davranışları", "restoranın fiziksel özellikleri”, "restoranın konfor özellikleri”, "yemeğin özellikleri”, "müzik" ve "niceliksel özellikler" şeklindedir. İlk boyut olan "personelin tutum ve davranışları" sekiz maddeden meydana geldiği, açıklanan varyans oranının \% 16,97 olduğu, öz değerinin 3,90 ve ortalamasının 4,19 olduğu sonucu elde edilmiştir. "Restoranın fiziksel özellikleri" boyutunun dört ifadeden oluştuğu, \% 11,37'lik varyansı açıkladığı, öz değerinin 2,61 ve ortalamasının 3,69 olduğu görülmektedir. "Restoranın konfor özellikleri” boyutu dört ifadeden oluşmakta, açıklanan varyans oranı \% 9,77, öz değeri 2,24 ve ortalaması 4,36 şeklindedir. "Yemeğin özellikleri” faktörü dört ifadeden oluşmakta, açıklanan varyans oranı \% 8,45, öz değeri 1,94 ve ortalaması ise 4,35 şeklindedir. "Müzik" boyutu tek ifadeden oluşmakta, açıklanan varyans oran $1 \% 6,80$, öz değeri 1,56 ve ortalaması 3,71 olarak görülmektedir. "Niceliksel özellikler" boyutu son olarak iki ifadeden oluşmakta ve açıklanan varyans oran $1 \% 6.20$, öz değeri 1, 43 ve 4,01 olarak görülmektedir.

Tablo 2. Restoran Özelliklerine Atfedilen Önem Boyutları

\begin{tabular}{|c|c|c|c|c|c|}
\hline & 竞 & 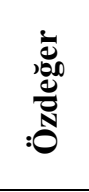 & 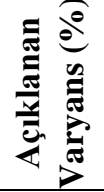 & 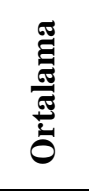 & 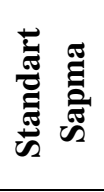 \\
\hline \multicolumn{6}{|c|}{ Personelin Tutum ve Davranışları (Personel Kalitesi) } \\
\hline Personelin yiyecekler hakkında bilgili olması & ,748 & \multirow{8}{*}{3,90} & \multirow{8}{*}{16,97} & \multirow{8}{*}{4,19} & \multirow{8}{*}{649} \\
\hline Personelin soruları tam ve doğru cevaplaması & ,731 & & & & \\
\hline Personelin hizmette istekli olması &, 713 & & & & \\
\hline Personelin birbirine karşı nazik olması & ,623 & & & & \\
\hline Karşılama ve uğurlama & ,621 & & & & \\
\hline Personelin dış görünümü ve temizliği & ,590 & & & & \\
\hline Personelin kibar ve güler yüzlü olmas1 & 569 & & & & \\
\hline Personelin sorunları seri bir şekilde çözmesi & ,562 & & & & \\
\hline \multicolumn{6}{|l|}{ Restoranın Fiziksel Özellikleri (Ortam Kalitesi) } \\
\hline Restoranın dekorasyonu & ,706 & \multirow{4}{*}{2,61} & \multirow{4}{*}{11,37} & \multirow{4}{*}{3,69} & \multirow{4}{*}{, 737} \\
\hline Personelin restorana uygun kiyafetler giymesi & ,692 & & & & \\
\hline Restoranın manzarası & 659 & & & & \\
\hline Restoranın 1S1S1 &, 532 & & & & \\
\hline \multicolumn{6}{|l|}{ Restoranın Konfor Özellikleri (Konfor Kalitesi) } \\
\hline Restoranın genel temizliği &, 713 & \multirow{4}{*}{2,24} & \multirow{4}{*}{9,77} & \multirow{4}{*}{4,36} & \multirow{4}{*}{, 580} \\
\hline Restoranın havalandırması & 657 & & & & \\
\hline Personelin restorana uygun kiyafetler giymesi & ,630 & & & & \\
\hline Restoranın oturma düzeninin rahatlığı &, 533 & & & & \\
\hline \multicolumn{6}{|l|}{ Yemeğin Özellikleri (Yemek Kalitesi) } \\
\hline Yiyeceğin tazeliği &, 738 & \multirow{2}{*}{1,94} & \multirow{2}{*}{8,45} & \multirow{2}{*}{4,35} & \multirow{2}{*}{, 523} \\
\hline Yiyeceğin sunumu & ,692 & & & & \\
\hline
\end{tabular}




\begin{tabular}{|l|c|c|c|c|c|c|}
\hline Yiyeceğin tadı &, 513 & & & & \\
\cline { 1 - 2 } Menü çeşitliliği &, 498 & & & & \\
\hline Müzik (Müzik Kalitesi) &, 700 & 1,56 & 6,80 & 3,71 & 1,120 \\
\hline Restorana uygun müzik yayını &, 802 & \multirow{2}{*}{1,43} & \multirow{2}{*}{6,20} & \multirow{2}{*}{4,01} & \multirow{2}{*}{, 760} \\
\hline Niceliksel Özellikler (Maliyet Kalitesi) &, 721 & Yiyeceğin miktar1 &
\end{tabular}

Sakarya restoranlarının niteliği konusunda katılımcıların değerlendirmelerini içeren ifadelerin alt boyutlara indirgenmesi amacıyla yine keşifsel faktör analizi yapılmıştır. Sonuçlar Tablo 3 'te verilmektedir. Buna göre "Sakarya restoranlarının niteliği konusundaki algı" boyutu yedi ifadeden oluşmakta, açıklanan varyans oran $\% 54,82$, öz değeri 3,83 ve ortalamas1 3,01 şeklindedir.

Tablo 3. Sakarya Restoranlarının Niteliği Konusundaki Algı

\begin{tabular}{|c|c|c|c|c|c|}
\hline & 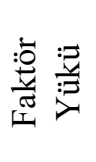 & 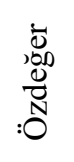 & 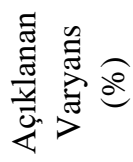 & $\begin{array}{l}\stackrel{\widetilde{\Xi}}{\tilde{J}} \\
\frac{\tilde{J}}{0} \\
0\end{array}$ & 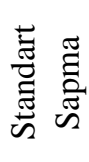 \\
\hline $\begin{array}{l}\text { Sakarya'da bulunan yiyecek-içecek işletmelerinde çalışanlar müşteriyi } \\
\text { anlar ve taleplerine duyarlıdır. }\end{array}$ &, 771 & \multirow{7}{*}{3,83} & \multirow{7}{*}{54,82} & \multirow{7}{*}{3,01} & \multirow{7}{*}{,727 } \\
\hline $\begin{array}{l}\text { Sakarya'da bulunan yiyecek-içecek işletmelerinde fiziksel donanım } \\
\text { yeterlidir. }\end{array}$ & ,764 & & & & \\
\hline Sakarya'da bulunan yiyecek-içecek işletmeleri kalitelidir. & ,743 & & & & \\
\hline $\begin{array}{l}\text { Sakarya'da bulunan yiyecek-içecek işletmeleri yeterli nitelikte personel } \\
\text { çalıştırır. }\end{array}$ & ,742 & & & & \\
\hline $\begin{array}{l}\text { Sakarya'da bulunan yiyecek-içecek işletmelerinde çalışanlar hizmete } \\
\text { isteklidir. }\end{array}$ & ,736 & & & & \\
\hline $\begin{array}{l}\text { Sakarya'daki yiyecek-içecek işletmelerinde gıda güvenliği ve hijyene } \\
\text { dikkat edilir. }\end{array}$ & ,716 & & & & \\
\hline Sakarya'da bulunan yiyecek-içecek işletmelerine her konuda güvenirim. & ,711 & & & & \\
\hline
\end{tabular}

$\mathrm{KMO}=, 860 ;$ ki-kare $=1227,527 ; \mathrm{df}=21$; Bartlett anlamlılık $(\mathrm{p}<0,05)$; açıklanan t. varyans \%54,82.

Katılımcıların kişilik özelliklerine ilişkin ifadelere verilen yanıtların aritmetik ortalaması ve standart sapma değerleri Tablo 4'te verilmektedir. Beş kişilik boyutuna ikili olumlu-olumsuz özelliklerin ortalamalarına bakıldığında, olumlu özelliklerin ortalaması 3,58 ile 3,92 arasında iken olumsuz özellikler 2,38 ile 3,01 arasında ortalamaya sahiptir.

Tablo 4. Kişilik Unsurlarına İlişkin Ortalama ve Standart Sapma Değerleri

\begin{tabular}{|c|c|c|}
\hline & 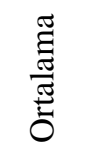 & 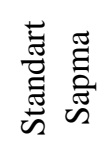 \\
\hline Yeni yaşantılara açık ve buna bağlı olarak da karmaşayla baş edebilir bir yapıya sahibim. & 3,62 & 1,124 \\
\hline Geleneksellikten çok hoşlanan ve buna bağlı olarak çok da yaratıcı olmayan birisiyim. & 2,82 & 1,164 \\
\hline Sempatik ve sıcak birisiyim. & 3,92 & 1,054 \\
\hline Eleştirel bakan ve dolayısıyla kavgacı birisiyim. & 2,80 & 1,282 \\
\hline Sakin ve buna bağlı olarak da duygusal olarak dengeli bir kişiyim. & 3,58 & 1,081 \\
\hline
\end{tabular}




\begin{tabular}{|l|c|c|}
\hline Kaygı̈lı ve kolaylıkla hayal kırıklığına uğrayan bir yapım var. & 3,01 & 1,206 \\
\hline Güvenilir ve bunu destekleyecek şekilde öz disiplinli bir kişiyim. & 3,87 & 1,014 \\
\hline Altüst olmuş ve buna bağlı olarak da dikkatsiz bir yapım var. & 2,38 & 1,216 \\
\hline Dışa dönük ve yaşam konusunda istekli bir yapıya sahibim. & 3,72 & 1,024 \\
\hline Çekingen ve sessiz bir yapıya sahibim. & 2,66 & 1,330 \\
\hline
\end{tabular}

\section{2. İlişki Analizi}

Elde edilen seçim kriteri boyutlarının kişilik özellikleri ile ilişkisine korelasyon analizi ile bakılmıştır. Korelasyon analizi, aralık ve rasyo seviyelerinden ölçülen iki değişken arasındaki ilişkinin veya bağımlılığın şiddetini belirleyen bir istatiksel analiz olarak ifade edilmektedir. Korelasyon değeri -1 ile +1 arasında değer almaktadır (Coşkun ve diğ., 2017). Korelasyon analizi yapılmasındaki amaç değişkenler arasındaki ilişkinin şiddetini tespit etmektir (Karasar, 2018). Bu kapsamda faktörler ve kişilik yapıları arasında ilişkinin miktarını belirleme adına yapılan ilişki analizi aşağıda verilmiştir (Tablo 5).

Bulgulara göre, restoranlarda personelin tutum-davranışları, restoranın konforu ve yemeğin özellikleri boyutuna verilen önemin yenilikçi kişilik düzeyiyle ilişkili olduğu tespit edilmiştir. Yani, restoran müşterilerinin yenilikçilik düzeyi arttıkça personel, konfor ve yemeğin özelliklerine önem verme düzeyi de artmaktadır. Öte yandan, gelenekçi kişilik düzeyi restoranın fiziksel özelliklerine verilen önemle ilişkilidir. Yani, restoran müşterilerinin gelenekçilik düzeyi arttıkça restoranın fiziksel özelliklerini önemli görme düzeyi de artmaktadir.

Sempatik kişilik özelliği ile personelin tutumu, restoranın konforu ve yemeğin özelliğine verilen önem düzeyi arasında ilişki tespit edilmiştir. Sempatik kişilik düzeyi arttıkça bu üç restoran özelliğine verilen önem düzeyi de anlamlı oranda artmaktadır.

Kavgacı kişilik ile personelin tutum ve davranışlarına verilen önem arasında ters yönlü bir ilişki bulunmuştur. Kavgacı özellik arttıkça personelin tutum ve davranışları daha az önemli görülmektedir. Dengeli kişilik yapısı için restoranın fiziksel özelliklerine verilen önem arasında düşük düzeyli ancak anlamlı bir ilişki vardır. Kaygılı kişilik özelliği ile konfor, müzik ve maliyete önem verme arasında bir ilişki bulunmuştur. Kaygılı kişiler için restoranın konforu, müziği ve maliyeti daha çok önemli görülmektedir. Disiplinli kişilik ile personelin tutum-davranışları ve konfora verilen önem arasında ilişki vardır. Bu tür kişilik özelliğine daha yüksek düzeyde sahip olanlar açısından personelin tutum-davranışları ve restoranın konforu daha önemli görülmektedir. Diğer taraftan dikkatsiz kişilik özelliği ile konfor ve yemeğin önemi ters yönlü bir ilişki içerisindedir. Yani dikkatsiz kişilik özelliği arttıkça restoranın konforu ve yemeğin özellikleri gibi unsurlara verilen önem azalmaktadır. Dışa dönük kişilik ile personelin tutum ve davranışları, restoranın sahip olduğu konforu ve yemeğin özellikleri arasında ilişki bulunmuştur. Dışa dönüklük arttıkça bu üç unsura ilişkin önem atfetme düzeyi de artmaktadır. Son olarak sessiz kişilik özelliği ile de restoranın fiziksel özelliklerine verilen önem arasında ilişki olduğu tespit edilmiştir.

Tablo 5. Restoran Seçim Kriterlerine Verilen Önem İle Kişilik Özellikleri Arasındaki İlişki

\begin{tabular}{|c|c|c|c|c|c|c|}
\hline Kişilik Boyutları & Personel & Fiziksel & Konfor & Yemek & Müzik & Maliyet \\
\hline Yenilikçi &, $175^{* *}$ & ,087 &, $153^{* *}$ &, $\mathbf{2 3 3}^{* *}$ & ,066 & 043 \\
\hline Gelenekçi & ,077 &, $169^{* *}$ &,- 002 & ,002 & ,024 & ,080 \\
\hline Sempatik/sıcak &, $157^{* * *}$ & 054 &, $119^{*}$ & ,104* & ,049 &,- 005 \\
\hline Kavgacı &,$- 116^{*}$ &,- 041 &,- 071 &,- 056 &, 048 & ,035 \\
\hline Dengeli & ,091 &, $095^{*}$ & 059 & ,069 & ,063 &,- 032 \\
\hline Kaygill & 063 & ,073 &, $096 *$ &,- 016 &, $156^{* *}$ &, $\mathbf{1 1 3}^{*}$ \\
\hline Disiplinli &, $127^{* *}$ &,- 048 &, $135^{* *}$ & ,079 & ,069 & ,033 \\
\hline Dikkatsiz &,- 075 &, 028 &,$- 096^{*}$ &,$- 128^{* *}$ &, 040 &,- 066 \\
\hline Dışa dönük &, $\mathbf{1 4 5}^{* *}$ & 052 &, $179^{* *}$ &, $142^{* *}$ &, 030 &,- 019 \\
\hline Sessiz & ,030 &, $\mathbf{1 7 0}^{* * *}$ & ,042 & 019 & ,012 & ,013 \\
\hline
\end{tabular}

$* * \mathrm{p}<0,01, * \mathrm{p}<0,05$ 
Yukarıdaki tabloda dikkat çeken en önemli unsur; yenilikçi, dışa dönük, sempatik ve disiplinli kimseler için personelin tutum ve davranışları, konfor ve yemeğin özelliklerinin ön planda değerlendirilmesi karşısında, gelenekçi ve sessiz yapıda kişiler için restoranın fiziksel unsurlarının ön planda olmasıdır. Bunun yanında, müzik ve maliyete verilen önemin yalnızca kaygılı kişilik özelliği ile ilişkili olması da dikkat çekici bir bulgudur.

Sakarya restoranlarının niteliğine ilişkin algılama düzeyi ile kişilik özellikleri arasında ilişki olup olmadığı korelasyon analizi ile test edilmiştir (Tablo 6). Yenilikçilik, dengelilik, disiplinlilik, dişadönüklük ve sessizlik kişilik özellikleri ile Sakarya restoranlarının niteliğine ilişkin algılama seviyesi önemli oranda ilişkili bulunmuştur. Yine; gelenekçilik ve sempatiklik özelliklerinin de Sakarya restoranlarına dair nitelik algısı ile \%95 güven aralığında ilişkili olduğu anlaşılmıştır (Tablo 7).

Sakarya restoranlarının niteliğine ilişkin algılama düzeyi ile kişilik özellikleri arasında ilişki olup olmadığı korelasyon analizi ile test edilmiştir (Tablo 6). Yenilikçilik, dengelilik, disiplinlilik, dışadönüklük ve sessizlik kişilik özellikleri ile Sakarya restoranlarının niteliğine ilişkin algılama seviyesi önemli oranda ilişkili bulunmuştur. Yine; gelenekçilik ve sempatiklik özelliklerinin de Sakarya restoranlarına dair nitelik algısı ile \%95 güven aralığında ilişkili olduğu anlaşılmıştır (Tablo 7).

Tablo 6. Kişilik Yapıları İle Sakarya Restoranlarının Algılanan Niteliği Arasındaki İlişki

\begin{tabular}{|c|c|c|c|c|c|c|c|c|c|c|}
\hline Kişilik Yapıları & 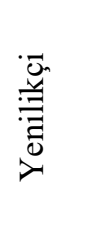 & 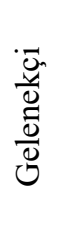 & 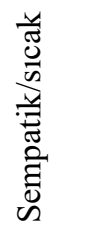 & 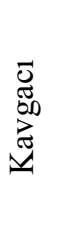 & $\begin{array}{l}\overline{\bar{D}} \\
\overline{0} \\
\overline{\bar{D}}\end{array}$ & 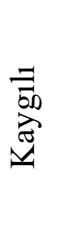 & $\begin{array}{l}: \bar{\Xi} \\
: \bar{n} \\
: \frac{\bar{n}}{0}\end{array}$ & 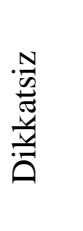 & 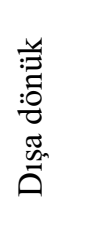 & $\begin{array}{l}\frac{N}{N} \\
\infty \\
\tilde{N} \\
\tilde{N}\end{array}$ \\
\hline \multirow{2}{*}{$\begin{array}{l}\text { Sakarya restoranları } \\
\text { hakkında } \\
\text { değerlendirme }\end{array}$} &, $185^{* *}$ &, $108^{*}$ &, $102^{*}$ & ,006 &, $168^{* *}$ & ,089 &, $155^{* *}$ &, 010 & $146^{* *}$ &, $125^{* *}$ \\
\hline & ,000 & 022 & ,031 & ,904 & ,000 & ,059 & ,001 & ,833 &, 002 & ,008 \\
\hline
\end{tabular}

$* * \mathrm{p}<0,01, * \mathrm{p}<0,05$

Restoran seçim kriterlerine atfedilen önem düzeyi ile Sakarya restoranlarına yönelik değerlendirmeler arasındaki ilişki korelasyon analiziyle test edilmiştir (Tablo 7). Restoranın fiziksel özelliklerine verilen önem ile Sakarya restoranlarının algılana niteliği arasında düşük düzeyde ilişki bulunmuştur. Demek ki, bir restoranda fiziksel unsurları daha önemli görenlerin Sakarya restoranlarını da nitelikli görme eğilimleri söz konusudur.

Tablo 7. Rest. Tercih Kriterlerine Verilen Önem İle Sakarya Restoranlarının Algılanan Niteliği Arasındaki İlişki

\begin{tabular}{|l|c|c|c|c|c|c|}
\hline & Personel & Fiziksel & Konfor & Yemek & Müzik & Maliyet \\
\hline \multirow{2}{*}{$\begin{array}{l}\text { Sakarya Rest. Hakkında } \\
\text { Değerlendirme }\end{array}$} &, 036 &, $117^{*}$ &, 032 &, 016 &, 082 &, 085 \\
\cline { 2 - 7 } &, 444 &, 013 &, 499 &, 730 &, 085 &, 073 \\
\hline
\end{tabular}

$* \mathrm{p}<0,05$

\section{SONUÇ VE ÖNERILER}

Araştırma kapsamında tüketicilerin en çok önem verdiği hususlar sırasıyla "restoranın konfor özellikleri $(4,36)$ ", "restoranın yemek kalitesi $(4,35)$ ", "personelin tutum ve davranışları $(4,19)$ ", "maliyet kalitesi $(4,01)$ ", "müzik $(3,71)$ " ve "restoranın fiziksel özellikleri $(3,69)$ "dir. Araştırma bu bulguları ile Albayrak (2014) ve Ertürk (2018)'in çalışmalarıyla benzerlik göstermektedir. Bu kapsamda rekabet avantajı elde etmek isteyen işletmelerin bu faktörleri dikkate alarak müşteri memnuniyeti sağlaması önem arz etmektedir.

Restoran işletmelerinde personelin tutum ve davranışları faktörünün yenilikçi, sempatik, kavgacı, disiplinli, dışa dönük kişilikler için önem arz ettiği sonucuna ulaşılmıştır. Fiziksel özellikler boyutu gelenekçi, dengeli ve sessiz kişilik yapısına sahip müşteriler için önemli olduğu sonucu elde edilmiştir. Restoranların konfor özellikleri sempatik, kaygıll, disiplinli ve dışa dönük müşteriler için önem atfetmektedir. Yemeğin kalitesi boyutuna yenilikçi, sempatik, dışa dönük kişilikler daha çok önem vermektedir. Müzik ve maliyet faktörü 
kaygılı kişilik için nispeten diğer kişiliklere göre daha fazla önem arz etmektedir. Bu kapsamda tüketicinin kişilik özelliğinin restoran tercihinde belirleyici olduğu ve kişilik yapılarına göre restoran tercih kriterlerine atfedilen önem düzeylerinin de farklılaştığı sonucuna ulaşılmıştır.

Sakarya restoranlarına ilişkin nitelik algısı ise kişilik boyutlarından kavgacı, kaygılı ve dengesiz kişilik özellikleri haricinde diğerleri ile anlamlı düzeyde ilişkilidir. Kişilik özelliklerinin belli bir bölgedeki restoranların niteliği üzerine algılamayla ilişkili çıkması kişilik faktörünün restoran tercihindeki rolünü ortaya koymaktadır. Diğer yandan, restoran tercih kriterlerine atfedilen önem boyutlarından yalnızca fiziksel özelliklere verilen önem ile Sakarya restoranları hakkındaki nitelik algısı ilişkili bulunmuştur. Bu durum yalnızca fiziksel özellikleri önemli görenler için Sakarya restoranlarının nitelikli olarak görüldüğü sonucunu ortaya çıkarmaktadır.

$\mathrm{Bu}$ çalışmanın bulgularına dayanılarak restoran tercihi gibi sektörel bir olgunun arka planında kişilik gibi bir sosyo-psikolojik olgu olduğundan hareketle, daha sonraki çalışmalara benzer değişkenleri kişilik öncülüyle birlikte ele almanın rasyonel olacağı önerilmektedir. Restoran işletmeleri için ise hedef kitle seçimlerinde ve tutundurma çalışmalarında pazarlama faaliyetlerini kişiliklere göre şekillendirme yararlı olacaktır. Bu hususu dikkate alan restoran işletmelerinin müşterilerine yönelik istek ve beklentileri tespit etmesinin daha kolay olacağ söylenebilir. Dolayısıyla beklentileri karşılanan müşterilerin restoran işletmelerine daha sadık olacağ 1 ifade edilebilir.

$\mathrm{Bu}$ çalışmanın en önemli sınırlılığı, zaman ve maliyet unsurlarından dolayı Sakarya ili Serdivan ilçesiyle sınırlandırılmış olmasıdır. Ayrıca yalnızca yerli katılımcılardan veri alınmış olması bir diğer sınırlılıktır. Gelecekte yapılması öngörülen çalışmalar farklı bölgelerde ve yabancı ziyaretçilerin katılımıyla gerçekleştirilerek, ortaya çıkan bulgular bu çalışma ile kıyaslanabilir. Araştırma restoran seçim kriterleri ve kişilik arasındaki bağı analiz etmiştir. Farklı nicel çalışmalarda kişilik ve demografik özellikler, davranışsal niyet gibi ikili değişkenler arasındaki ilişki incelenebilir. Restoran seçimi ve kişilik ilişkisi farklı etkenlerin dahil edildiği etkileşim modelleri ile de sınanabilir. 


\section{KAYNAKÇA}

Akşit. Aşık, N. (2019). Çocuklu Ailelerin Restoran Seçimlerini Etkileyen Faktörler: İzmir'de Bir Araştırma. Güncel Turizm Araştırmaları Dergisi, April, 150-168. https://doi.org/10.32572/guntad.512583

Albayrak, A. (2015). Müşterilerin Restoran Seçimlerini Etkileyen Faktörler: İstanbul Örneği. Anatolia: Turizm Araştırmaları Dergisi, 25(2), 190. https://doi.org/10.17123/atad.vol25iss255949

Almohaimmeed, B. M. A. (2017). Restaurant Quality and Customer Satisfaction. International Review of Management and Marketing, 7(3), 42-49

Arıker, Ç. (2012). Tüketicilerin Restoran Seçiminde Kullandıkları Seçim Kriterleri Demoğrafik Özellikleri Arasındaki İlişki. İstanbul Kültür Üniversitesi İ. İ B. F. İşletme Dergisi , 11-31.

Assaf, Deery ve Jago (2010), Evaluating the Performance and Scale Characteristics of the Australian Restaurant Industry, Journal of Hospitality and Tourism Research, 35(4): 419-436

Atak, H. (2013). On-Maddeli Kişilik Ölçeğinin Türk Kültürü’ne Uyarlanması\{Dotless\}. Noropsikiyatri Arsivi, 50(4), 312-319. https://doi.org/10.4274/npa.y6128

Bekar, A., \& Dönmez, G. F. (2016). Tüketicilerin Dışarıda Yemek Yeme Nedenlerine İlişkin Bir Değerlendirme. Social Sciences (Nwsasos), 7444(February 2015), 1-15.

Canoğlıu, M., \& Ballı, E. (2018). Tüketicilerin Kebap Restoranı Tercihlerini Etkileyen Faktörler - Adana Örneği. Organizasyon Ve Yönetim Bilimleri Dergisi, 10(1), 30-43

Cömert, M., \& Özata, E. (2016). Tüketicilerin Yöresel Restoranları Tercih Etme Nedenleri ve Karadeniz Mutfağı Örneği. Uluslararası Sosyal Araştırmalar Dergisi, 9(42), 1963-1973. https://doi.org/10.1017/CBO9781107415324.004

Çalışkan, O. (2013). Restoran İşletmelerinde Hizmet Hataları, Hizmet Telafi Stratejileri ve Müşteri Memnuniyeti İlişkisi. Seyahat ve Otel İşletmeciliği Dergisi, 10(3), 65-83. http://dergipark.ulakbim.gov.tr/soid/article/view/5000049470

Çetin, M., \& Yayli, A. (2019). Restoran Tercihinde Gösterişçi Tüketim Eğilimi. Turizm Akademik Dergisi, 6(2), 227238.

Çoşkun, R., Altunışık, R., \& Yıldırım, E. (2017). Sosyal Bilimlerde Araştırma Yöntemler Spss Uygulamalı (Sakarya Kitabevi).

Çulha, O., \& Dağkıran, S. (2016). Restoran İşletmelerinde Üst Düzey Çalışanlar Açısından Yöresel Yiyecekler: Faydalar, Engeller ve Satın Alma Ölçütleri. Anatolia Turizm Araştırmaları Dergisi, 27(2), $195-212$. https://doi.org/10.17123/atad.vol27iss20005

Dinçer, M. Z., \& Özdemir Güzel, S. (2018). The Effect of Restaurant s Physical Environment on Perceived Value, Customer Satisfaction and Loyalty: Case of Istanbul. Journal of Tourism and Gastronomy Studies, 6(4), 626-643. https://doi.org/10.21325/jotags.2018.327

Ekincek, S., \& Önçel, S. (2017). Sosyal Medyadaki Restoran Tüketici Yorumlarının Değerlendirilmesi: Foursquare Örneği - Evaluation of Restaurant Consumers Reviews in Social Media: The case of Foursquare. Journal of Business Research - Turk, 9(2), 404-419. https://doi.org/10.20491/isarder.2017.277

Ertürk, M. (2018). Müşterilerin Yiyecek İçecek İşletmeleri Tercihinde Etkili Olan Kriterler. Türk Turizm Araştırmaları Dergisi, 2(1). https://doi.org/10.26677/tutad.2018.

Filion, K., \& Powell, D. A. (2009). The Use Of Restaurant Inspection Disclosure Systems as a Means of Communicating Food Safety Information. Journal of Foodservice, 20(6), 287-297. https://doi.org/10.1111/j.17480159.2009.00151.x

Güllü, K., \& Atasoy, B. (2019). Gastronomi Turistlerinin Motivasyon Faktörlerinin İncelenmesi Investigation of Motivation Factors of Gastronomy Tourists. Anadolu Üniversitesi Sosyal Bilimler Dergisi, 19(4), 269-280.

Ha, J. (2018). Why Do People Try Different Restaurants? the Investigation of Personality, Involvement, and Customer Satisfaction. International Journal of Hospitality and Tourism Administration, 00(00), 1-15. https://doi.org/10.1080/15256480.2018.1511498

Hjalager, A.-M. (2003). Tourism and Gastronomy. In Tourism and Gastronomy In (Vol. 31, Issue 3, pp. 21-35). https://doi.org/10.1016/j.annals.2003.12.014

Islam, N., Mustafi, M. A. A., Ahmed, M. S., Rashid, M. M., Kabir, M. A. U., \& Nazrul, T. (2018). Factors Influencing the Selection of Restaurant for Dining in Dhaka City of Bangladesh. Global Journal of Management and Business Research, 18(7), 31-38.

Jollifie, L. (2002). Principal Component Analysis (Second). Springer.

Jung, J. M., Sydnor, S., Lee, S. K., \& Almanza, B. (2015). A conflict of choice: How consumers choose where to go for dinner. International Journal of Hospitality Management, 45(July 2018), 88-98. https://doi.org/10.1016/j.ijhm.2014.11.007

Karasar, N. (2018). Bilimsel Araştırma Yöntemleri (33rd ed.). Nobel Akademi Yayıncılık.

Kim, S., \& Chung, J.-E. (2011). Choosing restaurant Criteria: Understanding the Roles of Restaurant Typeand Customers' Socio-demographic Characteristics, Ohio State University. Global Journal of Management and Business Research, 5(7), 70-86. https://doi.org/10.1017/CBO9781107415324.004

Kivela, J., \& Crotts, J. C. (2006). Tourism and Gastronomy: Gastronomy's Influence on How Tourists Experience a Destination. Journal of Hospitality and Tourism Research, 30(3), 354-377. https://doi.org/10.1177/109634800628679 
Mason, K., Jones, S., Benefield, M., \& Walton, J. (2013). Consumer Perceptions of Quick Service Restaurants. Journal of International Business and Economics, 13(4), 109-116. https://doi.org/10.18374/jibe-13-4.8

McCrae, R. R., \& Costa Jr., P. T. (2008). The Five Factor Theory of personality. Handbook of Personality: Theory and Research, 159-181. https://doi.org/10.1016/S0191-8869(97)81000-8

Metz, J. (2014). Personality traits and food choice motives Explaining the intention of choosing organic products in restaurants, Master Thesis

Nişancı, Z., Özdoğan, Y., \& Bölüktepe, F. (2018). Dışarıda Yemek Yeme Davranışının Nedenlerini Belirlemeye Yönelik İzmir İlinde Bir Araştırma. İzmir Katip Çelebi Üniversitesi İktisadi ve İdari Bilimler Fakültesi Dergisi, 1(1), 6071.

Özdemir, B. (2010). Dışarıda Yemek Yeme Olgusu: Kuramsal Bir Model Önerisi. Anatolia: Turizm Araştırmaları Dergisi, 21(2), 218-232. https://doi.org/10.17123/atad.36402

Panthi, A., \& Karki, D. (2018). How Food Quality, Price, Ambiance and Service Quality Effects Customer Satisfaction : A study on Nepalese Restaurants in Finland.

Saygılı, M., Uslu, E. Mustafa, Onay, Ö., \& Akbulut, A. (2017). Yaşam Memnuniyetinin Kişilik Özellikleri Açısından İncelenmesi Metin. In A. Ay (Ed.), I. International Social and Economic Research Student Congress (pp. 465 477). https://doi.org/10.1038/1781332b0

TAVAK (2018), Türkiye’de Yeme-İçme Sektörünün Boyutları Gastronomi Ekonomisi (2018), https://tavakvakfi.org/wpcontent/uploads/2019/01/2018-Gastronomi-Ekonomisi-2018-converted.pdf, (Erișim: 20.01.2020).

Türkay, O. (2018). Fiyatlandırma ve Gelir Yönetimi. In Yiyecek-içecek Yönetimi, Detay Yayıncılık, (pp. 419-452).

Ulusoy, Öztan, Y., Akfırat, O. N., \& Tura, G. (2018). Ebeveynlere Bağlanma ile Kişilik Özellikleri Arasındaki İlişki. Resilience, 2(1), 23-38. https://doi.org/10.32569/resilience.436910

Untaru, E.-N., \& Neacşu, A.-N. (2012). Perceptıons of Restaurant Managers about The Quality of Products and Servıces Offered to Consumers. Case Study: The City Of Brașov. Revista de Turism: Studii Si Cercetari in Turism, 0(13), 5-13.

Van der Waldt, R., Greyling, M., \& Kotze, T. G. (2014). Customers 'Perceptions of Restaurant Experience in Gauteng. Contemporary Management in Theory and Practice, November, 149-157.

Yüksekbilgili, Z. (2014). A Research on Restaurant Preferences Criteria. Journal of Yasar University, 9(36), 6261-6380.

Yüksel, A., \& Yüksel, F. (2003). Measurement of Tourist Satisfaction With Restaurant Services: A Segment-Based Approach. Journal of Vacation Marketing, 9(1), 52-68. https://doi.org/10.1177/135676670200900104

Yüncü, H. R., \& Sevim, N. (2019). Yanlızlık Düzeylerine Göre Dışarıda Kahvaltı Yapma Alışkanlıklarının Değerlendirilmesi. 23, 1751-1766. 